PNNL-10942

UC-2000

\title{
TWRS Privatization Support Project Waste Characterization Resource Dictionary
}

\author{
GK Patello
}

KD Wiemers

September 1996

Prepared for

the U.S. Department of Energy

under Contract DE-AC06-76RLO 1830

Pacific Northwest National Laboratory

Richland, Washington 99352 


\section{DISCLAIMER}

This report was prepared as an account of work sponsored by an agency of the United States Government. Neither the United States Government nor any agency thereof, nor any of their employees, make any warranty, express or implied, or assumes any legal liability or responsibility for the accuracy, completeness, or usefulness of any information, apparatus, product, or process disclosed, or represents that its use would not infringe privately owned rights. Reference herein to any specific commercial product, process, or service by trade name, trademark, manufacturer, or otherwise does not necessarily constitute or imply its endorsement, recommendation, or favoring by the United States Government or any agency thereof. The views and opinions of authors expressed herein do not necessarily state or reflect those of the United States Government or any agency thereof. 


\section{DISCLAIMER}

Portions of this document may be illegible in electronic image products. Images are produced from the best available original document. 


\section{Contents}

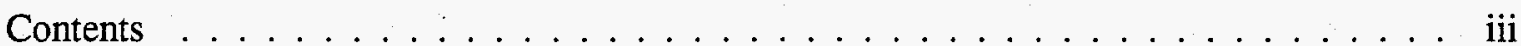

Figures $\ldots \ldots \ldots \ldots \ldots \ldots \ldots \ldots \ldots \ldots \ldots \ldots \ldots \ldots \ldots \ldots \ldots$

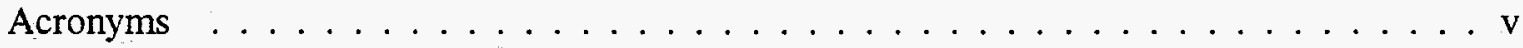

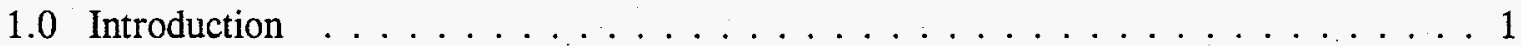

2.0 Waste Characterization Information Resources $\ldots \ldots \ldots \ldots$

Allen Report . . . . . . . . . . . . . . . . . . . . . . 9

Analytical Laboratory . . . . . . . . . . . . . . . . .

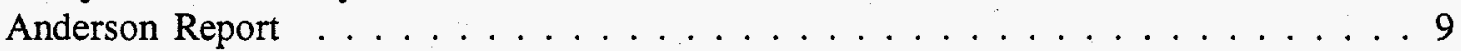

Braun Database . . . . . . . . . . . . . . . . . . 9

Characterization Daily Reports ..................... . . 9

Hanford Defense Waste Environmental Impact Statement . . . . . . . . . . . 10

Hanford Defined Wastes . . . . . . . . . . . . . . . . . 10

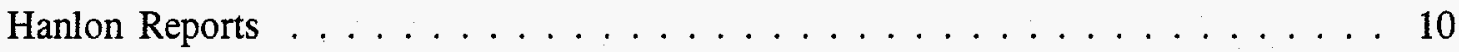

Historical Tank Content Estimates . . . . . . . . . . . . . . . . . . . 10

ICF Kaiser Hanford Company Database . . . . . . . . . . . . . . . . . . . . 10

Interim Safety Basis/Safety Analysis Report . . . . . . . . . . . . . . . . . 11

Inventory Estimates (General Definition-- applies to all inventories) . . . . . . . . 11

Jungfleisch . . . . . . . . . . . . . . . . . . . . . 11

Low-Level Tank Waste Inventory . . . . . . . . . . . . . . . . . . . 11

Low-Level Waste Feed Staging Plan . . . . . . . . . . . . . . . . 11

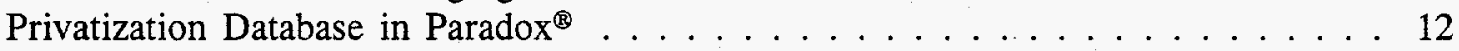

Reactor Process Records . . . . . . . . . . . . . . . . . . 12

Rouse Report . . . . . . . . . . . . . . . . . . . . 12

Surveillance Analysis Computer System . . . . . . . . . . . . . . 12

Safety Analysis Report (SAR) . . . . . . . . . . . . . . . . . . . 12

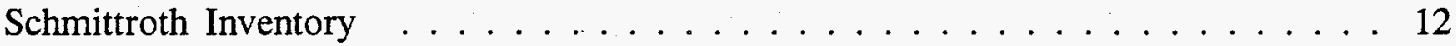

Tank Characterization Database .................... 13

Tank Characterization Report . . . . . . . . . . . . . . . . . 13

Tank Characterization Resource Center and Tank Farm Information Center $\ldots . .13$

Tank Layer Models . . . . . . . . . . . . . . . . . . . . . . . . . 13

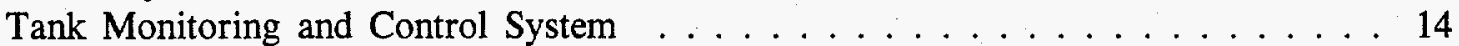

Tank Vapor Data Reports/Tank Vapor Safety Program . . . . . . . . . . . . . . 14

Tank Leakage Reports . . . . . . . . . . . . . . . . . . . . . . . . . 14

Tank Waste Information Network System . . . . . . . . . . . . . . . . . . 14

Tank Waste Remediation System Baseline Flowsheet Inventory . . . . . . . . . . 14

TWRS Privatization Double-Shell In-Tank Inventory . . . . . . . . . . . . 15

Tank Waste Source Term Inventory Validation . . . . . . . . . . . . . 15

Track Radioactive Components . . . . . . . . . . . . . . . . . . 15

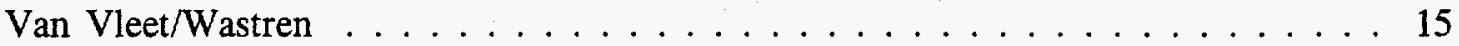

Waste Information Database System $\ldots \ldots \ldots \ldots \ldots$ 
Waste Status and Transaction Record Summary . . . . . . . . . . . . . 16

Waste Tank Summary Reports . . . . . . . . . . . . . . . . . . . 16

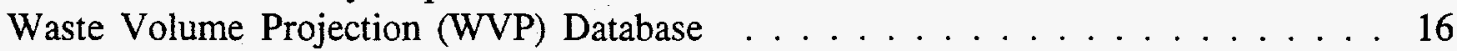

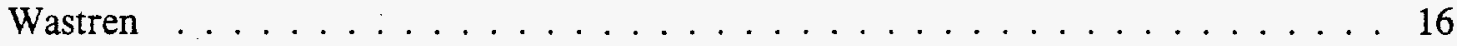

Westinghouse Hanford Company Supporting Documents . . . . . . . . . . 16

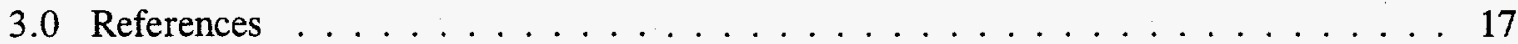

\section{Figures}

1. This diagram shows the information sources (i.e., process documents, databases and inventory estimates) for analytical data on tank wastes and the relationships between sources. The information flows selectively from one source to another depending on the objective of the document, database, or inventory. . . . . . . . . . 3

2. This diagram shows the information sources (i.e., process documents, databases, and inventory estimates) used to develop the Historical Tank Content Estimate (HTCE) and other inventory estimates and the relationships among the information sources. The information flows selectively from one source to another depending on the objective of the document, database, or inventory.

3. The diagram shows the information sources (i.e., process documents, databases, and inventory estimates) for the TWRS Privatization Double-Shell In-Tank Inventory and the relationships among the information sources. The information flows selectively from one source to another depending on the objective of the document, database, or inventory. 


\section{Acronyms}

$\begin{array}{ll}\text { CASS } & \text { Computer-Aided Surveillance System } \\ \text { CC } & \text { Complexant Concentrate } \\ \text { CP } & \text { Concentrated Phosphate } \\ \text { DC } & \text { Dilute Complexed } \\ \text { DN } & \text { Dilute Non-complexed } \\ \text { DOE } & \text { Department of Energy } \\ \text { DSS } & \text { Double-Shell Slurry } \\ \text { DSSF } & \text { Double-Shell Slurry Feed } \\ \text { HDAT } & \text { Handheld Data Acquisition Terminal } \\ \text { HDW } & \text { Hanford Defined Wastes } \\ \text { HDW-EIS } & \text { Hanford Defense Waste Environmental Impact Statement } \\ \text { HTCE } & \text { Historical Tank Content Estimate } \\ \text { ICF KH } & \text { ICF Kaiser Hanford Company } \\ \text { ISB } & \text { Interim Safety Basis } \\ \text { PNNL } & \text { Pacific Northwest National Laboratory } \\ \text { PUREX } & \text { Plutonium/Uranium Extraction Process } \\ \text { REDOX } & \text { Reduction/Oxidation Process } \\ \text { RFP } & \text { Request for Proposal } \\ \text { RMIS } & \text { Records Management Information System } \\ \text { SACS } & \text { Surveillance Analysis Computer System } \\ \text { SAR } & \text { Safety Analysis Report } \\ \text { TCD } & \text { Tank Characterization Database } \\ \text { TCR } & \text { Tank Characterization Reports } \\ \text { TCRC } & \text { Tank Characterization Resource Center } \\ \text { TFIC } & \text { Tank Farm Information Center } \\ \text { TLM } & \text { Tank Layer Models } \\ \text { TMACS } & \text { Tank Monitoring and Control System } \\ \text { TRAC } & \text { Track Radioactive Components } \\ \text { TWINS } & \text { Tank Waste Information Network System } \\ \text { TWRS } & \text { Tank Waste Remediation System } \\ \text { WHC } & \text { Westinghouse Hanford Company } \\ \text { WIDS } & \text { Waste Information Database System } \\ \text { WSTRS } & \text { Waste Status and Transaction Record Summary } \\ \text { WVP } & \text { Waste Volume Projection } \\ & \end{array}$

Note: A comprehensive glossary of Hanford terminology is provided by Agnew (1995). 


\subsection{Introduction}

A single estimate of waste characteristics for each underground storage tank at the Hanford Site is not available. The information that is available was developed for specific programmatic objectives (primarily safety and permitting) and varies in format and level of descriptive detail, depending on the intended application. Inventory estimates based on simplified assumptions were tailored to meet specific needs. Also, waste stream transfers to and from the tanks and aging continue to affect in-tank composition. Application of the available information, therefore, requires a thorough review of the source documents and a comprehensive knowledge of nuclear waste chemistry and tank farm operations.

The waste characterization information on the Hanford Site is available from many resources, including reports from Hanford's analytical laboratories, inventory estimates, historical processes and transaction records, databases with collections of analytical data and/or inventory estimates, and tank farm operation and surveillance record summaries. In addition, various technical reports and journal articles describe both waste characterization and laboratory process test results that are not identified in this dictionary but are listed in bibliographies that are available from the Department of Energy (DOE) reading room or on the Internet at http://twins.pnl.gov:8001/twrs_rfp/biblio/bibhome.htm.

This dictionary reflects an attempt to define what waste characterization information is available. It shows the relationship between the identified resource and the original data source and the inter-relationships among the resources; it also provides a brief description of each resource. Developed as a general dictionary for waste characterization information, this document is intended to make the user aware of potentially useful resources. However, some information is available only internally to the Hanford Site and is not publicly available. The publicily available documents may be requested through the Hanford Technical Library.

Despite the large number of intermediate and final products, the waste characterization information comes from two original sources: analytical data and operations records. Resources are primarily categorized as reports or databases. Descriptions and assessments of each resource are in the sections that follow. Resources are listed in alphabetical order. The relationships between the original sources and the resources are charted in Figures 1 through 3 . A list of acronyms is provided on page $\mathrm{v}$ of this report. 



\section{Analytical Data Resource Map}

$\begin{array}{ll}\square \text { Original Data } & \longrightarrow \text { Information flow } \\ \square \text { Database } & \longrightarrow \text { Documents }\end{array}$

* Available in Tank Waste Information Network System (TWINS)

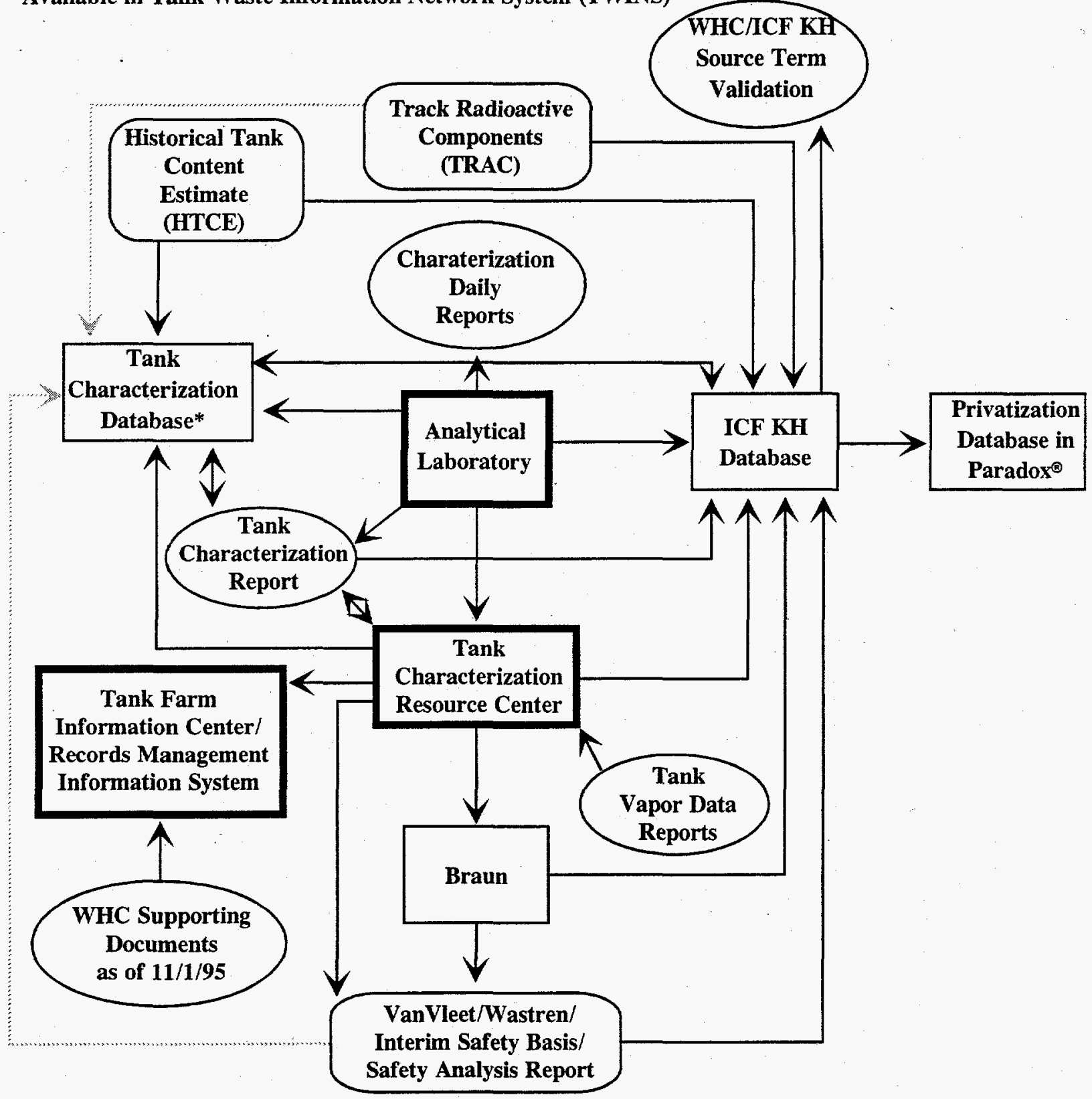

Figure 1. This diagram shows the information sources (i.e., process documents, databases and inventory estimates) for analytical data on tank wastes and the relationships hetween sources. The information flows selectively from one source to another depending on the objective of the document, database, or inventory. 
. 


\section{Inventory Resource Map}

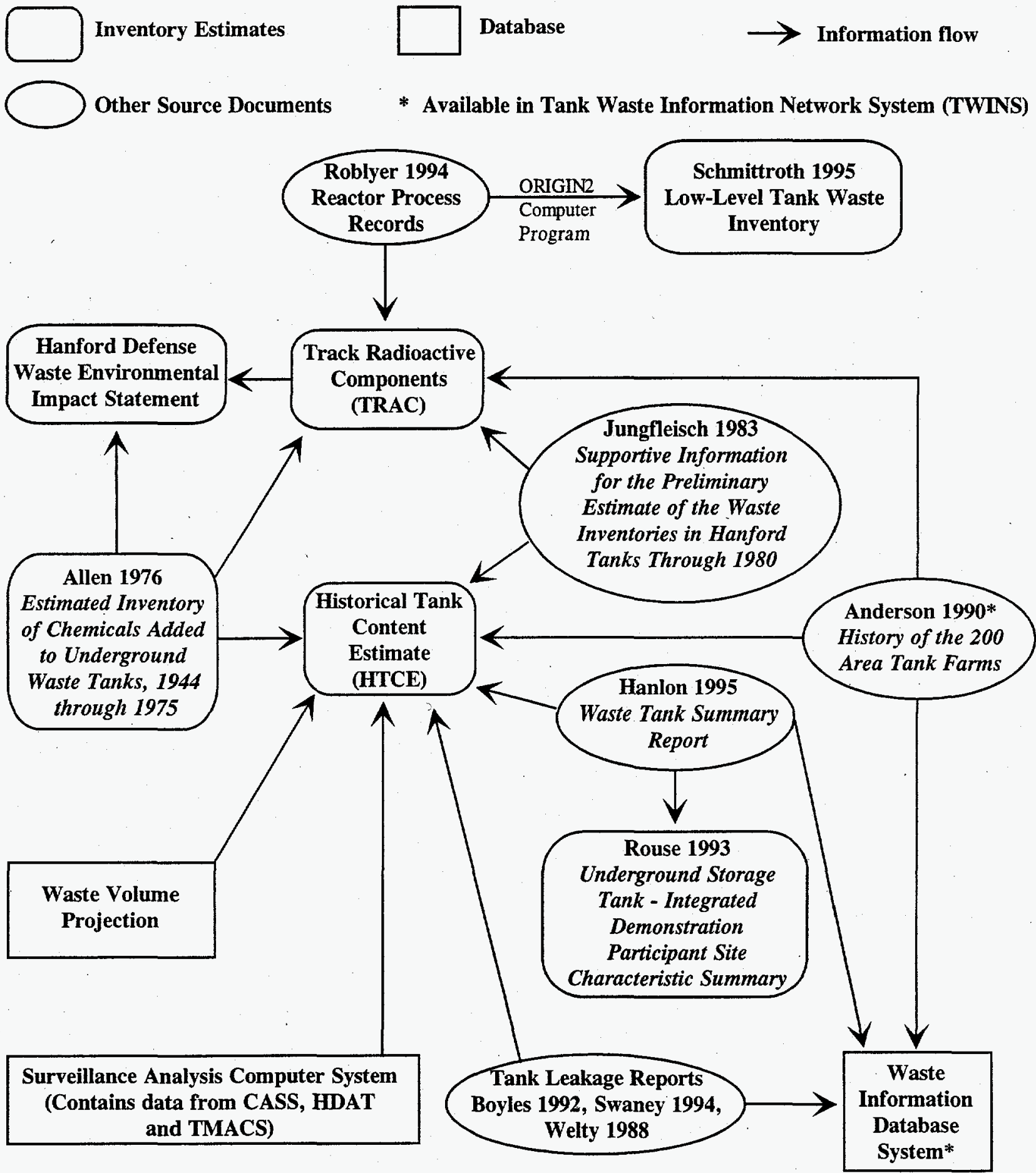

Figure 2. This diagram shows the information sources (i.e., process documents, databases, and inventory estimates) used to develop the Historical Tank Content Estimate (HTCE) and other inventory estimates and the relationships among the information sources. The information flows selectively from one source to another depending on the objective of the document, database, or inventory. 



\section{TWRS Inventory Resource Map}
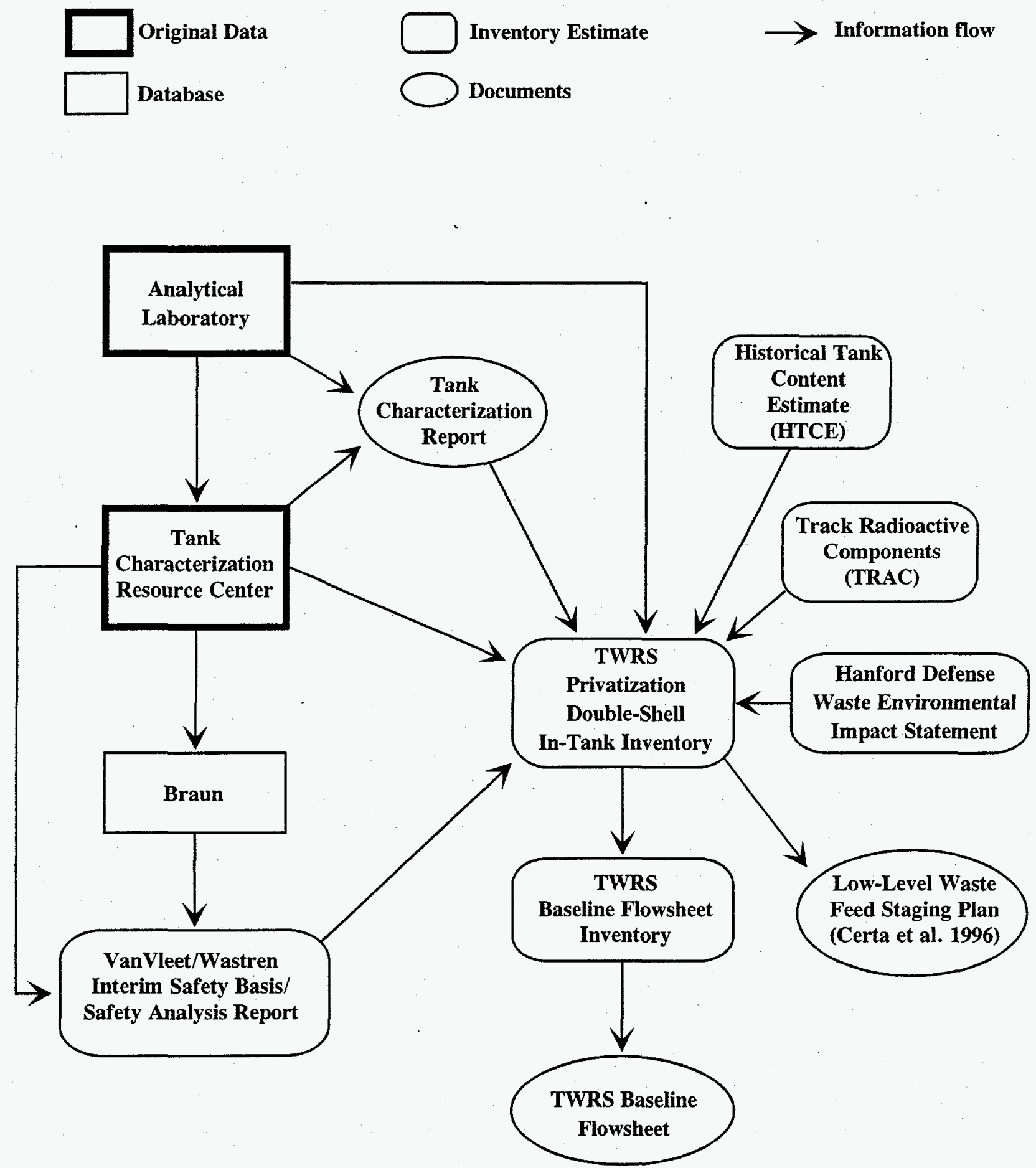

Figure 3. The diagram shows the information sources (i.e., process documents, databases, and inventory estimates) for the TWRS Privatization Double-Shell In-Tank Inventory and the relationships among the information sources. The information flows selectively from one source to another depending on the objective of the document, database, or inventory. 



\title{
2.0 Waste Characterization Information Resources
}

\begin{abstract}
Allen Report
The Allen report (Allen 1976) is an estimate of the inventory of chemicals added to the underground waste tanks during 1944 through 1975. Five major chemical processes--the $\mathrm{BiPO}_{4}$, Uranium Recovery, Reduction/Oxidation (REDOX), Plutonium/Uranium Extraction (PUREX), and Waste Fractionation--contributed to the total Hanford waste chemical inventory. The data for this report were compiled from process flowsheets, log records of actual chemicals used, and purchase orders for chemicals. Although some sample information is supplied, it is included only to facilitate validation of the chemical inventory basis.
\end{abstract}

\section{Analytical Laboratory}

New analytical data are retrieved directly from the analytical laboratories in Buildings 222-S and 325. The laboratories' analytical reports are filed in the Tank Characterization Resource Center (TCRC), entered into the Tank Characterization Database (TCD), and documented in the Tank Characterization Report (TCR). Variables that lead to uncertainties in the analytical data include sampling and handling techniques, analytical sample preparation and interferences, and interpretation of the results. The large number of heterogeneous tank wastes and the limited number of sample events call into question the accuracy of the data relative to the entire tank contents. Therefore, the analytical data must be viewed carefully in this context.

\section{Anderson Report}

The Anderson report (Anderson 1990) is a record of the history of liquid waste generation, handling, and storage in the tank farms at the Hanford Site. It reviews operations at the five major plants that have operated at the Hanford Site (the T and B plants, the Uranium Recovery plant, the REDOX plant, and the PUREX plant) and covers operating practices, tank auxiliaries, evaporative facilities, sluicing facilities, leak experience, salt-well pumping, tank stabilization, and isolation. Although this report does not provide tank-by-tank chemical or radionuclide inventories, a relatively complete history of the transactions involving each waste tank can be traced. The report is available at http://130.20.64.60:8001/anderson-contents.html.

\section{Braun Database}

The Braun database was developed by Dave J. Braun for the purpose of safety analysis. The database contains analytical data selected on the basis of highest concentrations for fissile material and lowest concentrations for neutron poisons (Brevick 1995b). These data are best represented in source documents at the TCRC.

\section{Characterization Daily Reports}

The Characterization Daily Reports, issued since February 1995, describe the day-to-day operations in the analytical laboratory related to safety, field sampling events, and laboratory sample analyses. Requirements for data quality objectives and Westinghouse Hanford Company (WHC) laboratory waste characterization support activities, such as test 
plans and technical findings, are also identified. These documents are available for internal use only.

\section{Hanford Defense Waste Environmental Impact Statement}

The Hanford Defense Waste Environmental Impact Statement (HDW-EIS) inventory estimate is based on information from the Track Radioactive Components (TRAC), the Allen document (Allen 1976), and miscellaneous process records. The HDW-EIS provides a Site-wide inventory and is not tank specific (DOE 1987).

\section{Hanford Defined Wastes}

Selected component concentrations for approximately fifty Hanford Defined Wastes (HDW) are estimated based on various sources, including chemical procurement records and process flowsheets (Agnew 1995). Assumptions regarding solubility and solids packing are based on analytical data. Radionuclide estimates are limited to plutonium-239, uranium-238, thorium-232, cesium-137, and strontium-90 (see also Historical Tank Content Estimates).

\section{Hanlon Reports}

See Waste Tank Summary Reports.

\section{Historical Tank Content Estimates}

The four historical tank content estimate (HTCE) documents (Brevick 1994a, 1994b, $1994 \mathrm{c}, 1995 \mathrm{a})$ provide inventories of the radioactive wastes stored in the 200-Area underground tanks by quadrant. These inventories were derived by reviewing the process histories and waste transfer data and entering the data into models that calculated tank waste composition. Information on waste definition and tank transfers, and the output of the models were document in the following reports: Waste Status and Transaction Record Summary (Agnew 1996a, 1996b, 1996c, 1996d), Tank Layer Model (Agnew 1996e), Supernatant Mixing Model and Hanford Defined Wastes (Agnew 1995). This information was then used to prepare the HTCE. The HTCE is an ongoing compilation of work performed during 1994 and 1995 by ICF Kaiser Hanford Company, Los Alamos National Laboratory, WHC, and Ogden Environmental as initiated by the Tank Waste Remediation System (TWRS) Characterization Project. Uncertainties in the HTCE are under evaluation.

\section{ICF Kaiser Hanford Company Database}

The ICF Kaiser Hanford (ICF KH) database is a compilation of analytical data and inventory estimates from the following sources: new analytical data, TCD, TCR, TCRC, Braun Database, Van Vleet/Wastren Database, HTCE, and TRAC. The database supports the Tank Waste Source Term Inventory Validation project (Brevick 1995b), which was performed by ICF KH and sponsored by WHC. The database provides information on 24 chemical analytes and 11 radionuclides. One limitation of the database is that analytical data are duplicated when the data are included in more than one source. The assumptions used to sort constituents between the liquid and solid phases require review for individual applications. Similar to the TCD, the database does not contain enough information to support interpretation of the data; therefore, the source documents must also be reviewed. 


\section{Interim Safety Basis/Safety Analysis Report}

The Interim Safety Basis/Safety Analysis Report (ISB/SAR) (Leach 1993) uses the information from Van Vleet (1993a, 1993b). The report provides estimated inventories derived from laboratory-sample data collected before 1990 from waste in each double-shell and single-shell tank. To provide a bounding envelope for safety analysis purposes, the largest radionuclide concentration values were normally used when multiple analyses from the same sample were available. No historic information was available for evaluation of data quality. Additional information that may be helpful in assessing the usefulness of these data can be found in the referenced documents.

\section{Inventory Estimates (General Definition-- applies to all inventories)}

Inventory estimates use historical process knowledge, waste transactions, or analytical data to predict tank waste composition. The concentration and inventory values may not represent actual tank status for a number of reasons, including that all predictions depend on historical weighting of the inventory bases, that is, the source terms and the distribution terms (how much was transferred into or out of a tank). Two major problem areas are

- incorrect source terms, which implies that incorrect flowsheet values were used and/or process work sheets or process histories were incomplete,

- incorrect distribution source terms, which implies that the transactions, the solubility, or the solids volume percent were incorrect. Transactions may be incorrect because they are unknown or misdirected; the incorrect solubility may be due to complexants in the waste.

Consequently, the estimated inventories must be viewed with caution. They are, however, believed to be more reliable for defining tank group compositions than for defining individual tank composition.

\section{Jungfleisch}

See Track Radioactive Components.

\section{Low-Level Tank Waste Inventory}

The Low-Level Tank Waste Inventory was developed by Schmittroth (1995). The inventory was derived by inputting reactor processing output records (Roblyer 1994) into a computer modeling program (ORIGIN2) to estimate total radionuclide production. The estimated radionuclide quantities were then adjusted to account for radionuclides shipped offsite (e.g., plutonium, technetium). This Site-wide inventory does not include constituents on a tank-by-tank basis.

\section{Low-Level Waste Feed Staging Plan}

The Low-Level Waste Feed Staging Plan developed by Certa et al. (1996) develops the sequence and transfer schedule for retrieval of double-shell tank supernatant by the management and integration contractor and delivery of the staged supernatant to the private low-activity waste contractors for treatment. A transfer system conflict analysis provides part of the basis for determining transfer system upgrade requirements to support delivery of both low-level and high-level waste feed. Waste feed is assigned to the Privatization Request for Proposal (RFP) envelopes (DOE 1996a, 1996b) using inventory estimates from 
TWRS Privatization Double-Shell In-Tank Inventory (Shelton 1996).

\section{Privatization Database in Paradox ${ }^{\circledR}$}

Paradox ${ }^{\otimes}$ is a Hanford Site-supported database (Johnson 1995). The TWRS Privatization Support Project Waste Characterization technical team conducted an independent analytical data review of selected double-shell tanks. The results are accessible in a database through Paradox ${ }^{\circledR}$ and as Excel ${ }^{\circledR}$ files from the Privatization homepage, http://twins.pnl.gov:8001/twrs_rfp/chardata/chardata.htm. The database contains 16 radionuclide and 36 analyte species from seven selected tanks, along with the references used. The user can either view the information on-screen or export a query. The onscreen view has the option of a record or spreadsheet view.

\section{Reactor Process Records}

See Low-Level Tank Waste Inventory

\section{Rouse Report}

The Rouse report (Rouse et al. 1993) provides "average" values for sludges, saltcakes, slurries, and supernatants. The amounts of each phase are based on information in the Waste Tank Summary Reports (see also Waste Tank Summary Reports). Information is taken from multiple DOE sites: Hanford, Savannah River, Oak Ridge, Idaho, and Fernald. The data on the Hanford Site, however, are not as thoroughly covered as in Site-specific documents.

\section{Surveillance Analysis Computer System}

The Surveillance Analysis Computer System (SACS) is an internal electronic database which stores tank farm surveillance data. The SACS receives data from the Tank Monitoring and Control System (TMACS), the Handheld Data Acquisition Terminal (HDAT), and the Computer-Aided Surveillance System (CASS). Data from remotely and manually operated detectors monitoring temperature, interstitial liquid levels, and surface level are sent to the database. The database includes data on all of the Hanford underground storage tanks, as well as other tanks including some catch tanks. It is a TriParty Agreement-related database and can be accessed through the Tank Waste Information Network System (TWINS).

\section{Safety Analysis Report (SAR)}

See Interim Safety Basis/Safety Analysis Report.

\section{Schmittroth Inventory}

See Low-Level Tank Waste Inventory. 


\section{Tank Characterization Database}

The Tank Characterization Database (TCD) contains existing and newly generated laboratory analysis data from 1985 to the present and inventory estimates from several sources, such as the TCR, the SAR, the HTCE, and TRAC. Older analytical data from records in the TCRC have been entered into the database by ICF-KH either from entries in their database or from original documents. Links to SAR and TRAC data were eliminated. Because the database does not contain enough information for interpretation of the data, the original references must also be reviewed. The TCD can be accessed at http://twins.pnl.gov:8001/TCD/main.html.

\section{Tank Characterization Report}

The tank waste inventories in the Tank Characterization Report (TCR) represent the final result of the waste characterization process and rely on many sources of information. Historical data are in the form of process knowledge, effluent discharges, and waste tank transfers. The result of the historical review is a detailed estimate of the contents of each waste tank based on process information and detailed transaction records. The TCR summarizes the results of sampling and analysis and qualitative and statistical interpretations. Several strategies, depending on the particular tank and its historical operations, are then used to reach a final estimate of the tank contents. Selected TCRs are available at http://www.hanford.gov/twrs/char.pub/doc_toc.htm

\section{Tank Characterization Resource Center and Tank Farm Information Center}

The Tank Characterization Resource Center (TCRC) in Building 2750 is a WHCcatalogued compilation of hard-copy analytical-sample information found in reports, memos, and letters. In addition to newer analytical data, this resource also contains characterization data generated before 1985 . The TCRC is a main source of reports containing waste characterization information. A significant number of these reports are not cleared for public release.

The hard-copy information in the TCRC is being scanned into the Tank Farm Information Center (TFIC) database. The database program is called Records Management Information System (RMIS). The TFIC database allows a user to search for documents according to tank number, document title, document number, author, date, or keywords. Because the process of scanning records into the database is not complete, the TFIC database does not contain all of the records that are filed in the TCRC. Since 11/1/95, all WHC documents have been scanned into the Records database which is also accessible through the RMIS program.

\section{Tank Layer Models}

The Tank Layer Models (TLM) (Agnew 1996e) provides estimates of types and amounts of sludge and salt cake in each of the 177 tanks. The Waste Status and Transaction Record Summary (Agnew 1996a, 1996b, 1996c, 1996d) data concerning waste volumes and solids level measurements support these derivations. (see also the HTCE and the Waste Status and Transaction Record Summary.) 


\section{Tank Monitoring and Control System}

The Tank Monitoring and Control System (TMACS) is an internal electronic database that receives and compiles data from a network of remote sensors. Over 1000 instruments in 80 underground tanks are monitored for surface-level, temperature, ventilation flows, and pressure. Alarms, such as those that detect flammable gas in the tanks, are also monitored. Information from the sensors is automatically entered into TMACS. TMACS can be used for historical and real-time trending of any measured parameter. Information gathered by TMACS is fed into the SACS database.

\section{Tank Vapor Data Reports/Tank Vapor Safety Program}

The Tank Vapor Safety Program was established in 1992 with the primary goal of providing a safe work environment that minimizes the use of supplied-air respiratory protection in the tank farms. The data collected from vapor space sampling are available in technical reports that are filed in the TCRC and may be accessed in the TFIC database. Many of the reports are also publicly available and can be accessed through the Hanford Technical Library.

\section{Tank Leakage Reports}

The reports by Welty (1988) and Boyles (1992) are a record of solids/liquid remnants and include the stabilization criteria for all single-shell tanks. These reports describe the nature, scope and frequency of tank surveillance, state action criteria for responses to data deviations, and present results of data reviews for June 15, 1973, through June 15, 1988.

The Boyles Report stems from the stabilization effort and contains similar information as that in the Welty document, including additional data about salt well pumping and stabilization of various tanks. Discrepancies among these documents and the Hanlon Reports have been addressed but not necessarily rectified in a subsequent report by Swaney (1993).

\section{Tank Waste Information Network System}

The Tank Waste Information Network System (TWINS) is a computer-based system for accessing characterization data. A variety of information is accessible through TWINS at http://twins.pnl.gov:8001/refmain.htm. Currently, parts of the database require a TWINS account. Data available through TWINS includes, but is not limited to

- information on the Site, such as geographic location, construction dates, operating status, and history

- data from the SACS database, including waste volumes, temperature, and radiation measurements

- analytical results from tank waste samples

- archived photographs, video clips, and audio narration.

\section{Tank Waste Remediation System Baseline Flowsheet Inventory}

The TWRS Baseline Flowsheet Inventory (Shelton 1995b) provides an inventory of all the double-shell and single-shell tanks as of February 1994. The purpose of the inventory was to provide input to TWRS baseline flowsheet calculations (Orme 1995). The inventory was compiled from new data sources, the HDW-EIS, HTCE, TCRC, TCRs, TRAC, and the Van Vleet/Wastren inventory (see Figure 3). For double-shell tanks, analytical data 
were given priority for establishing soluble and insoluble inventories. Other inventory predictions were used when analytical data were not available or out-of-date due to waste transfers. For single-shell tanks, HTCE data, normalized using the total inventory presented in the HDW-EIS, were used. Separation of soluble and insoluble fractions is based on water partitioning factors. The estimates do not necessarily represent in-tank waste compositions.

\section{TWRS Privatization Double-Shell In-Tank Inventory}

The TWRS Privatization Double-Shell In-Tank Inventory (Shelton 1995a) was derived from the TWRS Baseline Flowsheet Inventory for the privatization waste characterization effort. The inventory represents the contents of the double-shell tanks as of the date specified. The inventory is updated as new analytical information is received. Another version of the inventory projects waste composition to FY2002 for the purpose of developing a feed staging plan for privatization contractors (Shelton 1996).

\section{Tank Waste Source Term Inventory Validation}

The Tank Waste Source Term Inventory Validation (Brevick 1995b) report documents the results of a joint ICF KH and WHC project that assembled, organized, and interpreted sample data for use in developing radionuclide and toxic chemical source terms. The data are compiled in the ICF KH database.

\section{Track Radioactive Components}

The Track Radioactive Components (TRAC) computer code transactions (Jungfleisch 1984) estimate the amounts and distribution of selected radionuclides and stable chemicals in the total waste management system. Input data, based upon historical records, were used to create models of reactor, chemical process, and waste management. All computer codes, except isotope generation and depletion, were written within the scope of the TRAC project. These inventory estimates are preliminary. Data have not been satisfactorily audited, particularly, the process chemicals added and the waste management transactions. Computer codes have not been verified. Sampling and sample analysis have not been performed to validate predictions. The simulation spans 37 years of complex operational history and is untested. Data on plutonium and uranium are suspect because information was classified and, therefore, not accessible. Prudent application of the information developed in this study is recommended.

\section{Van Vleet/Wastren}

The Van Vleet/Wastren database is a compilation of sample information prior to 1990 prepared by Wastren, Inc. (a) that attempted to select the highest and most recent sample information from the Building 2750 tank characterization data archive (Van Vleet, 1993a, 1993b).

(a) Wastren, Inc. 1050 Gilmore Avenue, Suite C, Richland, Washington 99352. 


\section{Waste Information Database System}

The Waste Information Database System (WIDS) internal database provides a traceable source of information on historical, radiological surveillance, hazardous chemical, and environmental characterization data for all known waste sites at the Hanford Site.

Oversight of the database is maintained by Bechtel Hanford.

\section{Waste Status and Transaction Record Summary}

The Waste Status and Transaction Record Summary (WSTRS) reports (Agnew 1996a, 1996b, 1996c, 1996d) detail waste transfers into and out of single and double-shell tanks and is prepared from existing historical records such as TRAC computer code transactions and information in Anderson (1990). The reports are verified, as much as possible, by additional historical records. (see also HTCE and TLM.)

\section{Waste Tank Summary Reports}

These reports (also known as the "Hanlon Reports") have been issued monthly since June 1990; they are the "official" inventory of radioactive waste stored in the underground tanks in the 200 Areas (Hanlon 199x). The data in these reports indicate the status of tank vessel integrity, the amounts of stored radioactive waste, and the amount of waste in the following categories: sludge, salt cake, double-shell slurry (DSS), double-shell slurry feed (DSSF), complexant concentrate $(\mathrm{CC})$, concentrated phosphate $(\mathrm{CP})$, dilute non-complexed (DN), and dilute complexes (DC).

Data are provided on each of the 177 large underground waste storage tanks, 49 smaller catch tanks, and other special surveillance facilities. Supplemental information is also provided about tank surveillance anomalies and ongoing investigations. The Hanlon Reports derive information from the Welty/Boyles Reports and are based on best engineering judgments in many cases. Discrepancies occasionally exist between the two sets of reports.

\section{Waste Volume Projection (WVP) Database}

The WVP database is a compilation of the transaction histories for double-shell tanks from 1981 to present. This database was originally designed to meet waste volume projection needs and has been only issued in "Draft" form. Each entry is a record of either a historical or a projected activity for a specific tank. No tank-by-tank inventories are presented and, although various wastes types are named, no chemical compositions are given for the tanks. Periodic reports are issued containing waste volume information from the database (Koreski and Strode 1995).

\section{Wastren}

See Van Vleet/Wastren.

\section{Westinghouse Hanford Company Supporting Documents}

See Tank Characterization Resource Center (TCRC) and Tank Farm Information Center (TFIC). 


\subsection{References}

Agnew SF. 1995. Hanford Defined Wastes: Chemical and Radionuclide Compositions. LAUR-WR-94-2657, Rev. 2, Los Alamos National Laboratory, Los Alamos, New Mexico.

Agnew SF. 1996a. Waste Status and Transaction Record Summary for the Northeast Quadrant. WHC-SD-WM-TI-615, Rev. 1, Westinghouse Hanford Company, Richland, Washington.

Agnew SF. 1996b. Waste Status and Transaction Record Summary for the Northwest Quadrant of the Hanford 200 West Area. WHC-SD-WM-TI-669, Rev. 1, Westinghouse Hanford Company, Richland, Washington.

Agnew SF. 1996c. Waste Status and Transaction Record Summary for the Southeast Quadrant of the 200 Area. WHC-SD-WM-TI-689, Rev. 1, Westinghouse Hanford Company, Richland, Washington.

Agnew SF. 1996d. Waste Status and Transaction Record Summary for the Southwest Quadrant. WHC-SD-WM-TI-614, Rev. 0, Westinghouse Hanford Company, Richland, Washington.

Agnew, SF, et al. 1996e. Hanford Tank Chemical and Radionuclide Inventories: HDW Model. LA-UR-96-858, Rev. 3, Los Alamos National Laboratory, Los Alamos, New Mexico.

Allen GK. 1976. Estimated Inventory of Chemicals added to Underground Waste Tanks, 1944 through 1975. ARH-CD-610 B, Atlantic Richfield Hanford Company, Richland, Washington.

Anderson JD. 1990. A History of the 200 Area Tank Farms. WHC-MR-0132, Westinghouse Hanford Company, Richland, Washington. (Originally prepared in 1979, with O. C. Mudd, now published with revisions, June 1990).

Boyles VC. 1992. Single-Shell Tank Leak Stabilization Record. WHC-SD-RE-TI-178, Rev. 3, Westinghouse Hanford Company, Richland, Washington:

Brevick CH. 1994a. Historical Tank Content Estimate for the Northwest Quadrant of the Hanford 200 West Area. WHC-SD-WM-ER-351, Rev. 0, ICF Kaiser Hanford Company, Richland, Washington.

Brevick CH. 1994b. Historical Tank Content Estimate for the Southwest Quadrant of the Hanford 200 West Area. WHC-EP-0762, Rev. 0, ICF Kaiser Hanford Company, Richland, Washington.

Brevick CH. 1994c. Historical Tank Content Estimate for the Northeast Quadrant of the Hanford 200 East Area. WHC-SD-WM-ER-349, Rev. 0, ICF Kaiser Hanford Company, Richland, Washington. 
Brevick CH. 1995a. Historical Tank Content Estimate for the Southeast Quadrant of the Hanford 200 East Area. WHC-SD-WM-ER-350, Rev. 0, ICF Kaiser Hanford Company, Richland, Washington.

Brevick CH. 1995b. Tank Waste Source Term Inventory Validation.

WHC-SD-WM-ER-400, Rev. 0, ICF Kaiser Hanford Company, Richland, Washington.

Certa PJ, WH Grams, CM McConville, LW Shelton, and EJ Slaathaug. 1996. Low-Level Waste Feed Staging Plan. WHC-SD-WM-PRT-224, Rev. 0, Westinghouse Hanford Company, Richland, Washington.

DOE. 1987. Disposal of Hanford Defense High-Level, Transuranic and Tank Wastes. DOE/EIS-0113, Vol 1-5, Department of Energy, Washington DC.

DOE. 1996a. TWRS Privatization Request for Proposal, Solicitation Number DE-RP0696RL13308, Department of Energy, Richland Office, Richland, Washington.

DOE. 1996b. Amendment of Solicitation/Modification of Contract, Tanks Waste Remediation System (TWRS) Privatization. Amendment 001 to Solicitation DE-RP06-96-RL 13308, U.S. Department of Energy, Richland, Washington.

Hanlon BM. 199x. Waste Tank Summary Report for Month Ending xxxxxxxxxxxxxxx. WHCEP-0182-xx, Westinghouse Hanford Company, Richland, Washington.

Johnson ED. 1996. TWRS Privatization Support Project Waste Characterization Database Development. PNNL-10971, Pacific Northwest National Laboratory, Richland, WA.

Jungfleisch FM. 1983. Supportive Information for the Preliminary Estimation of the Waste Inventories in Hanford Tanks through 1980. SD-WM-TI-058, Rockwell Hanford Operations, Richland, Washington.

Jungfleisch FM. 1984. Preliminary Estimation of the Waste Inventories in Hanford Tanks through 1980. SD-WM-TI-057, Rockwell Hanford Operations, Richland, Washington.

Koreski GM and JN Strode. 1995. Operational Waste Volume Projection.

WHC-SD-WM-ER-029, Rev. 21, Westinghouse Hanford Company, Richland, Washington.

Leach CE and SM Stahl. 1993. Hanford Site Tank Farm Facilities Interim Safety Basis, Vol. I and II. WHC-SD-WM-ISB-001, Rev. 0-E, Westinghouse Hanford Company, Richland, Washington.

Orme RM. 1995. TWRS Process Flowsheet, Revision 1. WHC-SD-WM-TI-613, Westinghouse Hanford Company, Richland, Washington.

Roblyer SP. 1994. Plutonium and Tritium Produced in the Hanford Site Production Reactors. WHC-SD-CP-RPT-014, Westinghouse Hanford Company, Richland, Washington. 
Rouse JK, TJ McLaughlin, SP Airhart, EJ Jensen, SL Lindberg, DD Robinson, and JM Cruse. 1993. Underground Storage Tank - Integrated Demonstration Participant Site Characteristic Summary. WHC-EP-0566, Westinghouse Hanford Company, Richland, Washington.

Schmittroth FA, TH DeLorenzo, DW Wootan, and DY Garbrick. 1995. Inventories for Low-Level Waste Tank Waste. WHC-SD-WM-RPT-164, Rev. 0, Westinghouse Hanford Company, Richland, Washington.

Shelton LW. 1995a. Supernate/Sludge Compositions for Double-Shell Tanks. Internal Memo to JA Voogd dated 1 August 95. Westinghouse Hanford Company, Richland, Washington.

Shelton LW. 1995b. Chemical and Radionuclide Inventory for Single and Double-Shell Tanks. Internal Memo to RM Orme dated 8 August 95. Westinghouse Hanford Company, Richland, Washington.

Shelton LW. 1996. Projected Double-Shell Tank Supernatant Compositions for Phase I Privatization. WHC-SD-WM-TI-751, Rev 0, Westinghouse Hanford Company, Richland Washington.

Swaney SL. 1993. Waste Level Discrepancies Between Manual Level Readings and Current Waste Inventory for Single-Shell Tanks. WHC Internal Memo, \#7C242-93-038, December 10, 1993, Westinghouse Hanford Company, Richland, Washington.

Van Vleet RJ. 1993a. Radiological and Chemical Inventories for Double-Shell Tanks. WHC-SD-WM-TI-543. Westinghouse Hanford Company, Richland, Washington.

Van Vleet RJ. 1993b. Radionuclide and Chemical Inventories for Single-Shell Tanks. WHC-SD-WM-TI-565, Westinghouse Hanford Company, Richland, Washington.

Welty RK. 1988. Waste Storage Tank Status and Leak Detection Criteria. SD-WM-TI-356, Vol. 1 \& 2, (Originally Report: RHO-CD-213), Westinghouse Hanford Company, Richland, Washington. 


\section{Distribution}

No. of

Copies

2 DOE/Office of Scientific and Technical Information

\section{OFFSITE}

Steve Agnew

Los Alamos National Laboratory

Mail Stop J586

Los Alamos, NM 87545

John FitzPatrick

Los Alamos National Laboratory

CST-7 G739

Los Alamos, NM 87545

\section{ONSITE}

Department of Energy

Rob Gilbert

K6-51

2 Kaiser Hanford Company

Chris Brevick

S3-10

Eric Johnson
No. of

Copies

4 Westinghouse Hanford Company

Mike Kupfer

H5-27

Ivar Husa

R1-30

Brad Schaffer

R2-12

Louis Shelton

H5-49

16 Pacific Northwest National Laboratory

Penny Colton

K2-25

Langdon Holton

K9-73

Gert Patello (2)

K7-14

Katherine Savard

K9-04

Karyn Wiemers (2)

K6-51

Delores Vela (2)

K6-51 